\title{
Implementation of International Legal Principles for Judicial Remedy Of Participants in Economical Relations as a Warranty for Sustainable Development of Ukraine
}

\author{
Vadym Koverznev ${ }^{1}$
}

\begin{abstract}
The article systemizes the Fundamental principles for activity of judicial authorities, which are formulated in different leading international acts and discovers their legal essence. It is proved that the implementation of the international legal principles of the judicial remedy in the national legislation of Ukraine is a warranty not only to ensure the proper protection of the rights for participants in economic relations but also the sustainable development of the entire state.

The author of the article analyzes the progress in implementation of the international legal principles of judicial remedy in the national legislation of Ukraine within the framework of judicial and legal reform, which was conducted in 2016, and sets out the proposals, aimed at improving the situation in the field of extrajudicial dispute settlement (mediation).
\end{abstract}

Keywords: principles of judicial remedy, sustainable development, participant in economical relations, access to court, independent court, fair trial, effectiveness of judicial protection, mediation.

\section{Introduction}

Paragraph 2 in Strategy for Development of Economics "Ukraine 2020" (hereinafter referred to as the Strategy), aimed to implement European living standards in Ukraine and to put the state to the leading positions in the world, defines the security vector, which provide with the security guarantees for business and citizens, protection of investments and private property, as one from the main movement vectors in Ukraine.

The Strategy refers not only the ability of the state to protect its borders, to guarantee the peace in its territory and in European region as a whole to Ukraine's security factor but also the ability to ensure the fair and impartial justice, immediately to carry out purges of power at all levels, and to provide with implementation of effective mechanisms for combating corruption [1].

Creating the honest and impartial justice in Ukraine is impossible without implementation of the modern international standards in the field of legal proceedings into national legislation and taking into account the experience from organization of activity by judicial branch of power in leading democratic countries of the world. 


\section{Typology (classification) of international legal principles for activity of court}

The international standards in the field of legal proceedings are defined in leading documents by the United Nations Organizations (hereinafter referred to as the UN), Council of Europe (hereinafter referred to as the CE) and the Consulting Council of European Judges, which can be classified due to the following groups at the general level.

\subsection{General principles for independence of judicial authorities and judges}

The general standards for independence of courts and judges are formulated, first of all, in Fundamental Principles for Independence of Judicial Authorities. approved by resolutions 40/32 and 40/146 by the General Assembly of the United Nations, dd. 29, November and 13, December 1985 [15], which establish the duty of States to guarantee the independence of the judicial authorities at the constitutional level, the duty of all state bodies and other institutions to respect the independence of judicial authorities and to adhere to it. According to this document, judicial authorities should be able to deal with the cases, brought to them, impartially, on the basis of facts and in accordance with the law, without any restrictions, unlawful influence, pressure, threats, or direct or indirect interference from any side. The jurisdiction of judicial authorities shall extend to all disputes, with each state is obliged to provide with the necessary means for performance of its functions by the national judicial authorities. The term of judges' powers, their independence and security, the conditions of service and retirement shall be guaranteed exclusively by law.

European Charter about Law "On Status of Judges", adopted by Council of Europe in 1998, directs Member States to adopt the special law on the status of judges, aimed at ensuring the competence, independence and impartiality of persons, expected from the courts and each judge separately. The Charter defines the general criteria to select the candidates to positions of judges, their appointment, and promotion, conditions for transfer to other courts, as well as the procedure to bring a judge to responsibility in case of failure or improper fulfillment of his duties [13].

The above-mentioned acts substantiate the need for independence of court as a precondition for the rule of law and the fundamental guarantee of a fair trial.

Taking into account that judges have a duty to resolve legal disputes and to make a final decision, the independence of a judge and a court is considered not as a prerogative or a personal privilege to protect the interests of the judge but solely in the context of the need to ensure the rule of law and guarantees of the rights at those persons, who are looking for justice in court. Such justice shall exist both in relation to a particular natural person or a legal entity and to the society in general. The abovementioned envisages not only the possibility to bring a subject of private law to responsibility for its deeds but also the state, in case of failure to fulfill or improper fulfillment of its positive obligations to the person.

In order for judicial authorities to have the opportunity to perform its functions and protect the rights of persons, including against violations by the state, it shall be independent on state authorities and such independence shall be traced at any stage of its operation - from selection of judicial staff and ending with suspension and resignation 
of judges. The independence of judicial authorities is ensured exclusively at the legislative level and in accordance with the international standards.

The selection of candidates to positions of judges shall be based on the objective criteria of professional quality and personal integrity, which are subject to clear formulation and communication to the public, while excluding political considerations and subjective approach. The career advancement of a judge shall depend solely on his/her qualifications and the quality of the administration of justice, which is assessed by a body that is completely independent on the executive and legislative power.

The special attention is paid to the issue about position of a judge. Thus, the UN Fundamental Principles and European Charter about Status of Judges do not exclude the possibility to appoint the judges for a fixed term or for an examination period but modern European practice makes it expedient to appoint judges to permanent positions (i.e. before retirement), which provides with the highest guarantee for independence of a judge on external influence. Nevertheless, in some European countries, the appointment of judges for a certain period of time (for example, the judges for Federal Constitutional Court of Germany are appointed for 12 years). However, such practice is permissible and justified for countries with developed democracy, in which the independence of the court and judges is recognized and respected by all legal entities but is undesirable for countries that are in a position to build a democratic society, including Ukraine, as the respect for and compliance with the rule of law in such countries are generally not ensured at the proper level.

UN Fundamental Principles (paragraph 2) recommend States to impose the sanctions in the national legislation on persons, who seek to exert pressure on the court or judges in any way, in order to protect the judicial authorities against unlawful influence. In addition to independence on external influence, judges shall be independent and internally secured by an independent division of cases between judges of a particular court, the deprivation of judges, holding the administrative positions in a court, the possibility for influence from other judges on administration of justice, as well as development of judicial self-government, with the simultaneous provision of judicial self-government bodies with powers to consider any issues, related to the activities of a particular court and to make decisions that are mandatory for execution of court chairmen.

On this occasion, the report by European Commission "For Democracy through Law" (Venice Commission) on the independence of judicial authorities, dd. 12-13, March, 2010 states: "The independence of the judicial system contains an objective component as an inherent characteristic of the judicial system, and the subjective component, which is the right of a person to determine its rights and duties as an independent judge. Without independent judges, there can be no proper and legitimate exercise of rights and freedoms, so the independence of the judicial system is not an end in itself. This is not a personal privilege of judges but a necessity, based on ensuring that judges can act as guards of human rights and freedoms" [14].

The right to an independent and impartial court at European level is guaranteed by Article 6 of the European Convention for the Protection of Human Rights and Fundamental Freedoms (Rome, 4, November, 1950), which states that everyone has the right to a fair and public hearing of its case within a reasonable time by an independent and impartial court, established by law [9]. 


\subsection{Professional ethics and conduct of judges, ensuring an appropriate level of justice}

The position of a professional judge is sufficiently specific as judge is not an ordinary employee of the court but a person, acting on behalf of judicial authorities and embodying the administration of justice. The abovementioned requires the formalization of the special status for a judge at the legislative level, on the one hand, and the definition of specific requirements for behavior of a judge in the society that forms the trust of the members to such a society in the court and judicial authorities as a whole, due to the trust and respect of a separate judge on the other.

Recognizing the special status of a judge in the society, the Resolution by UN Economic and Social Council, dd. 27.07.2006 No 2006/23, approved Bangalore Principles of Judicial Conduct, based on Universal Declaration of Human Rights and the International Covenant on Civil and Political Rights, while guaranteeing the equality of everyone to a court of law, as well as the right of a person to timely consideration of a case, connected with the establishment of its rights and obligations in an open court session in accordance with the procedure, established by law [6].

The Bangalore Principles are aimed at establishing standards for the ethical conduct of judges and designed to promote better understanding and support for the administration of justice by the executive and legislative authorities.

The Bangalore Principles of Judges Conduct include:

- the principle for independence of judges and judicial authorities as a prerequisite of law and order in the country and a guarantee of a fair trial in a court of law, which is considered in individual and collective aspects;

- the principle of objectivity, which manifests itself not only in the content of the decision but also in the procedural actions of the judge, involved into consideration of the case. According to this principle, a judge can not show any sympathy or prejudice to the participants of the case, while refraining from commenting on the case. In cases, where the participants in the case may have the objective reasons to doubt the impartiality or objectivity - such a judge shall declare a self-rejection;

- the principle of honesty and integrity, which requires a judge to demonstrate such conduct that even for a third-party observer it will be considered impeccable and build the confidence in honesty and integrity of judicial power branch;

- the principle of adherence to ethical norms, which prohibits to manifest the conduct of a judge in professional activities and everyday life, which requires a high status of a judge in the society. Based on this principle, a judge shall not use its professional status to resolve personal issues. It is precisely on the grounds of the formation of a positive attitude at the society towards judicial authorities, judges, subject to proper fulfillment of their duties, are allowed to engage in literary, creative and scientific activities on a paid basis;

- the principle of equality, which anticipates the duty of judge's equal treatment to all participants of the case, regardless of their social status, material status, nationality, sex, sexual orientation, etc.;

- the principle of competence and diligence, which imposes the duty on the judges continually to improve their professional level, to observe the changes in the legislation and judicial practice of the higher courts, to respect the dignity and to be polite to the participants of 
the case, properly to motivate their decisions, for the parties to feel be heard by the court.

As the judges can not be isolated from the society, they in their everyday life should not be engaged in acts that may harm the authority of the court and jeopardize their independence and impartiality in the eyes of an outside observer, including during participation in public discussions concerning the national justice policy.

The abovementioned rule is enshrined in the Conclusion By Consulting Council of European Judges, dd. 19.11.2002, No. 3 (2002) [8].

\subsection{Requirements for organization of court activity and communication of judicial power with the society}

The judicial power of any state is a system of judicial authorities, empowered by national legislative acts to resolve legally relevant cases in accordance with established procedures of legislation and jurisdiction.

As a part of the system, individual courts need proper the organization of work that will ensure the preservation of skilled personnel, avoid significant material and organizational costs in the organization of justice and try the cases, based on the rule of law.

To this end, the Committee of Ministers of the Council of the European Union adopted

a Recommendation to Member States on measures to prevent and to reduce the excessive workload in courts on 16.09.1986 No. R (86) 12, which, taking into account the steady growth of cases, submitted to the courts and that may damage the rights of each public hearing of the case within a reasonable time, is proposed to the Member States:

- to provide with legislative procedures for reconciliation and out-of-court settlement of disputes,

- to impose the duty on the judges to facilitate the amicable settlement of disputes by all possible means at any stage of court proceedings,

- to consider the ethical duty of lawyers or a specially designated body to promote the reconciliation between the parties both before commencement and at any stage of the trial,

- to reduce the number of tasks, entrusted to judges, which are not related to the implementation of legal proceedings and entrust their implementation to other bodies,

- periodically to review the competence of different courts in order evenly to distribute the load [18].

The conclusion by Consulting Council of European Judges on financing and management of courts in the context of judicial authorities efficiency, dd. 23, November, 2011, No. 2 (2001), it was recognized that due funding of courts is closely related to the issue about independence of judges as it determines under what conditions the judges work. The Consulting Council agreed that, despite the fact that the financing of courts is carried out at the expense of the state budget, such funding should not depend on the political situation in the state, and the decisions, related to the allocation of funds for the work of courts, shall be taken with the strict observance of principle for division of power and respect for independence of judicial power branch.

The formation of respect and trust in justice is impossible without establishing the appropriate communication between the judicial power branch and society as a whole, as well as its individual groups and members [10].

Realizing the importance of this aspect in public relations, the Consulting Council of European Judges adopted the conclusion "Justice and Society", dd. 25, November, 2005, 
No. 7 (2005), which noted that the development of democracy in European states means that citizens should receive the proper information about function of judicial system, which is an important element of a democratic society. In addition to communicating through the media, courts shall establish the direct communication with the public, educate students and be transparent. It is the courts that shall disseminate the information about access to justice, through periodic reports, printed publications, the Internet, etc.

The courts shall not only participate in framework programs, organized by other government institutions (higher education institutions, Ministry of Justice, etc.) but also organize their own information activities. To do this, it proposes to establish the persons, responsible for receiving citizens and informing the public about the work of the court; conducting the educational forums by courts, open meetings with public organizations and individual citizens; introduction and information filling of own Internet sites; introducing the positions of judges-speakers, who will be responsible for communication with mass media and the public and timely bringing to their attention the resonance cases, which are being considered in court, as well as the results of their consideration, in the structure of courts of departments.

In order to avoid any misunderstandings and conflict situations, it is proposed to develop the codes of judges' professional conduct in their relations with journalists.

The open trial of cases involves the unhindered presence of media in court sessions and the possibility to inform the public about significant events that take place in court.

In order to improve the relations with the participants of the case, it is proposed to equip the special courts with prosecutors, lawyers and ordinary participants in court premises in order to ensure that they can be familiarized with the case files or with comfortable expectations for commencement of trial.

\subsection{Standards of court process quality and effectiveness of rights protection}

Taking into account that access to justice shall not depend on the material provision of a person, the Committee of Ministers of the Council of the European Union has adopted Resolution No. 76 [19] on free legal aid in civil, commercial and administrative affairs, which recommended that the governments of Member States render the legal assistance in civil, economic and administrative matters both to their own citizens and citizens of any Member State, regardless of the nature of the court that exercises the jurisdiction.

The resolution is based on the fact that no person shall be deprived of its remedies at courts due to economic obstacles, and therefore such person shall have the access to free legal aid in the state in court proceedings. Free legal aid shall cover all expenses, incurred by the person, to whom it is provided, including lawyers' fees, costs of forensic examination, reimbursement of expenses for interpreter services and witnesses. Free legal aid shall be provided exclusively by a person, who has the status and practice of a lawyer. The free legal aid shall be funded at the expense of the state.

The Recommendations of the Committee of Ministers of the Council of Europe on measures to facilitate the access to justice, dd. 14.05.1981 № R (81) 7 [20], formulated the principles for protection of a person in a court, in particular, by: 
- informing the public about location and jurisdiction of courts, as well as the procedure for appeal in court for the protection of their interests, on the existing procedural rules and means of implementing a court decision,

- taking measures to maximize the reduction of time limits for passing judgments,

- defining the amount of legal expenses that shall be reasonable and not impede the access to justice.

It should be noted that the effectiveness of legal proceedings consists not only in providing the factual access to a court but also in the legislative introduction of such judicial procedures that guarantee the possibility to settle the cases within a reasonable time, as well as the actual enforcement of court decisions.

In accordance with the Recommendation by the Committee of Ministers of the Council of Europe (95) 5, the tripartite judicial system, which provides with the possibility to challenge a court decision, is effective, while preventing a person from abusing this right and reducing the burden on the courts.

The UN Human Rights Committee has adopted General Comment No. 32, Article 14: Right to Equality before the Courts and Tribunals and for a fair trial (July 9-27, 2007), in which it noted that the right to a fair trial is an essential element in the protection of human rights and serves as one of the procedural elements in the rule of law; Article 14 of the Covenant proclaims a general guarantee of equality to the courts and tribunals, which is applicable, irrespective of the nature of the trial. This principle should be respected by all Member States, regardless of their legal traditions and internal legal system. An honest and open hearing of a case by a competent, independent and impartial tribunal is the next principle, enshrined in Article 14.

The article also embodies the principle of ne bis in idem, which states that no one can be twice brought to justice for an offense, for which he/she has already been punished..

Recommendations by the Committee of Ministers of the Council of Europe on principles of civil justice, aimed at improving the function of justice, dd. 28.02.1984 No. R (84) 5 [21], define the fundamental principles of effective civil justice, namely:

- judicial proceedings shall consist of no more than two court sessions (the first meeting is preparatory, and during the second session the court hears the arguments of the parties, examines the evidence and makes a decision),

- the court shall be able to apply the sanctions to the persons, who do not appear at the call of a court, do not comply with his instructions or abuse their procedural rights,

- in order to ensure a speedy review of the case, the court shall have the opportunity to play an active role in the proceedings,

- in appraising the appeal, the court of appeal shall not take into account any evidence, which was not the subject of a trial at the court of first instance, except in the cases, where a person was deprived of the opportunity to provide a court with evidences,

- the courts shall have the most advanced technical means to administer the justice in the most favorable conditions for its effectiveness, in particular by facilitating the access to various sources of law.

In accordance with the case law of the European Court of Human Rights, the enforcement of a judicial decision is the final stage of judicial proceedings as if the final judicial decision remains unperformed, the protection of the rights, freedoms and interests of a person is considered to be illusory.

Under such circumstances, the establishment of an effective system of judicial enforcement is one of the elements in building a legal and democratic state. 
The Recommendation by CE Committee of Ministers on enforcement, dd. 09.09.2003, No. Rec (2003) 17 [22], indicates that the enforcement procedures shall be based on the norms of national legislation and be as effective as possible. The states shall establish a mechanism to prevent from the cases of abuse of the enforcement procedure by one of the parties, which shall not be considered as a revision of the case. The forced execution shall not be postponed unless there are any legal grounds for this. The enforcement procedure shall be clearly defined and provide with effective means of execution and counteracting the abuse of rights by the parties.

The Conclusion by Consulting Council of European Judges on the role of judges in enforcement of judgments, dd. 19.11.2010 No. 13 (2010), states that the effective enforcement of court decisions is a fundamental element in the rule of law; the procedure for court to execute the decisions shall be implemented in accordance with the rights and freedoms, provided for in Articles 3, 5, 6, 8, 10, 11 of the European Convention. The concept of an "independent court", through the prism of Article 6 in the Convention, means that the authority of the court to make the binding decisions can not be subject to subsequent approval, and that a non-judicial body, including the head of state, can not modify or cancel that decision. Any suspension or postponement in execution of a court decision can only take place by taking another court decision. The execution of a court decision shall not require the initiation of a new court proceeding, and the execution procedure shall not allow any reconsideration of the case. The states are required to create the appropriate conditions for enforcement, and to provide with access to debtors databases and information about their assets.

The real implementation of court decisions strengthens the public confidence in the powers of judicial authorities and judicial power branch as a whole. The enforcement of judgments shall be swift, effective and proportionate, and should be in accordance with the fundamental rights and freedoms, recognized by the European Convention. Regardless of the means of execution, the procedure for enforcement of court decisions must be impartial and subject to judicial control.

\subsection{Alternative methods to settle the disputes (mediation)}

The mediation significantly differs from judicial procedures for dispute settlements as it anticipates more active position of the parties under dispute and their personal participation in work over project of future settlement.

The main task of mediator is to direct the joint efforts by the parties to settle a dispute applying the special techniques. The participation of the parties in procedure for dispute solution, using mediation, does not deprive them of the right to pass their dispute to court consideration further, if it is impossible to achieve the agreement, using mediation procedure.

The advantages of mediation may include the confidential character of this procedure. Besides, while performing the mediation, the parties are not bound with formal procedures; the mediation does not anticipate making any significant expenses, related to payment for appearance of witnesses, performance of court examinations, collection of evidences, etc.

The rules of mediation in family disputes are approved by Resolution from EC Committee of Ministers, dd. 21.01.1998 No R (98)1. The rules anticipate the possibility 
for their application to all disputes between members of the same family, which relate to blood or marital relations, and all, who live in family relations. The parties are free to choose a mediator, who shall be neutral and impartial as to the parties under dispute, hereby, is not entitled to impose its own decision to the parties, which does not suit them. Settling a dispute, a mediator shall prompt the parents to concentrate, first of all, on the needs and interests of a child and provision with its welfare. The states are proposed to anticipate the procedures for cessation of judicial proceedings in case if the parties showed the desire to use the mediation.

The recommendation by EC Committee of Ministers as to mediation in civil cases, dd. 18.09.2002 No Rec (2002) 10, defines that the term "mediation" concerns the process for settlement of disputes, within which the parties run the negotiations on disputable issues in order to achieve the consent, involving one or some mediators. The mediation in civil cases shall be organized by the most private way, using a state or private arbiter and may be performed on a judicial and extrajudicial basis. The states shall define the standards for selection and responsibility of mediators, provide with their training and periodic qualification improvement. The process of mediation shall provide the parties with sufficient time for consideration of disputable issues and conclusion of agreement. In their turn, the mediators shall explain the consequences from arrangements, received by the parties, and inform about events, which shall be taken to perform these arrangements.

The important feature of mediation is the confidentiality, which is very important to preserve a secret of public and family life, as well as to keep the trust between the parties. Besides, the mediation is the largest available way to settle a dispute, considering the absence of need in expenditure of funds to pay the court procedures and attorney's fees. The significant role in mediation process belongs to judges and attorneys, who shall explain the possibility about dispute settlement on an extrajudicial basis to the parties and assist them to use the mediation procedure.

On 16, June, 2011 UN Human Rights Council adopted the resolution, which approved the Leading Principles of Business Activity within the aspect of human rights (hereinafter referred to as Leading Principles) that exceed the obligations, undertaken by UN state members, to be followed to, to respect and to defend the human rights and fundamental freedoms, as well as to provide with their efficient remedies [23].

Among Fundamental Leading Principles there is a duty of the state to provide with human rights defense against infringements by any third parties in its territory that includes not only the performance of preventive (prophylactic) and law enforcement activity but the regulatory provision with efficient legal proceedings.

The implementation of this Fundamental principle in Ukraine anticipates the state's implementation of free access to the remedies at legislative level, including human remedy in business sphere.

The Leading Principles also oblige State Ukraine to establish the efficient mechanisms for human remedies and to take actions to reduce the barriers, which complicate the access to the national institutions of human remedies.

Thus, the Leading Principles require establishing such national judicial system, which corresponds to the criteria for efficiency in protection of infringed rights and availability of human remedies, freedoms and interests [16, c. 72]. 
Taking into consideration the provisions in Article of Convention for the Protection of Human Rights and Fundamental Freedoms, according to which everyone is entitled for fair and public consideration of his/her case during the reasonable period by independent and impartial court, established by law and precedent practice of European Human Rights Court, which mentioned in decision, dd. 12, October, 1978, in case "Zand v. Austria" mentioned that the word expression "established by law" covers both the legal basis for existence of "court" and observance of norms that regulate its activity by such court [12], it is reasonable to distinguish one more Fundamental international principle - principle of legitimacy (legality) in function of national court.

\section{Implementation of international legal principles in court activity into national legislation of Ukraine}

Performing its international legal obligations and continuing the course for implementation of judicial legal reform, on 02, June, 2016 Verkhovna Rada of Ukraine adopted the Law No 1401-VIII, which introduced the changes into Constitution of Ukraine, in particular, into section VIII "Justice" [11].

Article 124 in Constitution of Ukraine extended the court jurisdiction to any legal dispute and other cases, which legislation refers to court settlement; implemented the consideration of certain case categories by jury in order to involve the people into justice realization.

The Constitution warrants the independence and immunity of judges through direct prohibition of influence on a judge without consent from the Higher Council of Justice until such judge passes a court guilty verdict, except the detention of a judge during or at once after committal of a grave or especially grave crime; implemented the termless occupation of post by a judge and prohibited to bring a judge to liability for approved judgment, except the case for committal of a crime or a disciplinary offence (Art. 126). The Constitution defines the exclusive list of grounds to dismiss a judge from the post, which includes the impossibility to perform the powers due to health status; judge's infringement of requirements as to incompatibility; committal of essential disciplinary offence; a rough or systematic ignorance of duties that is incompatible due to judge's status or found out its non-conformity to occupied post; submission of application about retirement or dismissal from the post due to own desire; disagreement for transfer to another court in case of liquidation or reorganization of court, where a judge occupies the post; infringement of duty to confirm the legality in source of property origin.

The President of Ukraine appoints a judge to the post due to presentation by Higher Council of Justice exclusively due to contest, which procedure of performance is defined by Law of Ukraine "About Judicial System and Judge Status".

According to Article 129 in Constitution, making the justice, a judge is independent and applies the rule of law. The main principles of legal proceedings include the equality of all participants in judicial process to the law and court, competitiveness of the parties and freedom in their provision of court with own evidences and proof of their persuasiveness to the court, publicity of judicial process and its complete registration by technical facilities, reasonable periods for consideration of case by court, provision with right for appeal reconsideration of case and in cases, defined by law - to cassation appeal of judgment, obligingness of judgment. 
The activity of Higher Council of Justice is anticipated in order to provide with independence of court power branch and judge at constitutional level, which competence includes the introduction of submission about appointment of judge to the post, approval of decision in relation to judge's infringement of requirements as to incompatibility, consideration of complaints and bringing a judge to the disciplinary liability, approval of decision about dismissal of judge from the post, provision with consent to arrest a judge or to take him/her into custody, taking actions to provide with independence of judges.

The Higher Council of Justice is an independent authority in system of judicial bodies and consists of twenty one members, ten ones of which are elected by Congress of Judges of Ukraine from a number of judges or retired judges, two ones are appointed by President of Ukraine, two ones are elected by Verkhovna Rada of Ukraine, two ones are elected by Congress of Attorneys of Ukraine, two ones are elected by all-Ukrainian Conference of Prosecutors, two ones are elected by Congress of Representatives From Legal Higher Schools and Scientific Institutions. The Chairman of Supreme Court is included into composition of Higher Council of Justice due to the post. The period of powers for elected (appointed) members in Higher Council of Justice is four years; hereby the same person cannot occupy the post of member in Higher Council of Justice for two terms in succession (Art. 131).

Thus, the modern international legal warranties for independence of court and judges were formalized in Ukraine at constitutional level and establish the prerequisites for their proper function and implementation of justice.

The new wording in Law of Ukraine "About Judicial System and Judge Status" No 1402VIII, adopted by Verkhovna Council of Ukraine on 02, July, 2016, defines the organization of judicial power in Ukraine and implementation of justice pursuant to the rule of law according to European standards and provides everyone with the right for fair court.

The Law No 1402-VIII, unlike the previous one that was effective until 29, September, 2016, establishes the three branched judicial system in Ukraine, which includes the Supreme Court that is the highest court in judicial system, as well as court of appeals and local courts [2].

The Law No 1402-VIII implements the specialization of courts in consideration of civil, criminal, economical, administrative cases, as well as cases about administrative offences. Taking into consideration the kinds of specializations (jurisdictions), defined by the Law No 1402-VIII, it is anticipated that the local district common, economical and administrative courts would function in Ukraine, as well as appropriate general, economical and administrative courts of appeal that act at appropriate districts of appeal. The essential warranty of court independence is the norm of Article 19, which anticipates that the establishment or liquidation of court is carried out exclusively by the law, which draft is introduced by the President of Ukraine after consultations with the Higher Council of Justice.

The Law No 1402-VIII clearly defines the powers of court chairmen and make their influence on judges impossible in any way that is the increase in warranties of independence at judges. 
Article 58 in Law No 1402-VIII obliges the judges to follow to the Code of Judicial Ethics, approved by the XI regular congress of judges of Ukraine on 22, February, 2013, which defines the standards for honest behavior of a judge both while he/she makes the justice and extrajudicial behavior [7]. In particular, a judge shall be an example of steady observance of law and principle for rule of law, observance of high standards in behavior in order to form the trust at citizens in honesty, independence, impartiality and fairness of court; to avoid any illegal influence into its activity, related to implementation of justice; diligently and impartially to perform own professional duties and to take actions to deepen their professional knowledge; to show the tactfulness, politeness, self-control and respect to participants in judicial process and other persons; not to allow any infringement in principle for publicity of process and provide the mass media with possibility to receive the information about cases, hereby not allowing any infringement in rights and freedoms of citizens, humiliation of their honesty and dignity; to refrain from public declarations and comments about cases, being in his/her proceedings, in mass media, and to doubt any judgments that entered into legal force; to avoid extra procedural relations with participants under case; not to misuse the right to recusal; not to take part in political or public activity and public actions that cause any harm to authority of court; to be aware of own property interests and to take actions to be aware about property interest of members in own family; to apply the allowable forms of communication in the internet and to comment the information, placed there, without any harm to justice.

Articles 89-91 in Law No 1402-VIII oblige the professional judges to pass through regular training at National School of Judges of Ukraine and regular assessment for detection and improvement in level of knowledge.

Law No 1402-VIII implemented the judges' self-government to protect the professional interests of judges and to settle the issues of courts' internal activity, which task is the independent collective settlement of abovementioned issues by judges.

The judges' self-government is one from the main warranties for provision with independence of judges and is designed to assist to establishment of organizational conditions to provide with normal activity of courts and judges, to consolidate the independence of court, to provide with protection of judges against interference into their activity, to improve the level in work with staff in system of judges.

Part Four Article 126 in Law No 1402-VIII includes the settlement of the following issues into the tasks of judges' self-government:

1) to provide with organizational unity in function of judicial power authorities;

2) to consolidate the independence of courts, judges, protection of judges' professional interests, including the protection against interference into their activity;

3) participation in definition of needs in staff, financial, material technical and other provision of courts and control for observance of established norms for such provision;

4) election of judges to administrative posts at courts due to procedure, established by this Law;

5) appointment of judges to Constitutional Court of Ukraine;

6) election of judges to composition of Higher Council of Justice and Higher Qualification Commission of Judges of Ukraine due to procedure, established by law. 
Law, dd. 03.10.2017, No 2147-VIII entered into force on 15, December, 2017, which sets forth Civil Procedural Code of Ukraine, Economical Procedural Code of Ukraine and Code of Administrative Legal Proceedings of Ukraine in new wording [17].

Law No 2147-VIII unifies the judicial procedures that significantly simplifies the work of specialists in the sphere of law, who, on a professional basis, perform the representation of interests at legal entities and natural persons in courts of different jurisdictions as it defines the same rules for consideration by civil, economical and administrative courts, except certain categories of cases, which are inherent only to certain jurisdictions, in particular: cases, which are considered due to the rules of certain proceedings pursuant to procedure of civil legal proceedings, or cases about bankruptcy of debtor, which are considered by civil courts, or disputes with certain categories for subjects of power authorities (President of Ukraine, Verkhovna Rada of Ukraine, Cabinet of Ministers of Ukraine, Central Elective commission, Higher Council of Justice, Higher Qualification Commission of Judges of Ukraine, ministry or other central authority of executive power), which are considered due to special judicial administrative courts, defined by Code of Administrative Legal Proceedings of Ukraine.

The effective procedural code of Ukraine implements the consideration of civil, economical and administrative cases pursuant to principles for publicity of judicial process that anticipates the open consideration of cases and the possibility for any person to be present in the open judicial hearing. The persons, who are present at the hall of court hearing, and the representative of mass media are entitled to perform photography, video and audio recording of judicial process, using the portable video and audio facilities without separate permit of court (such permit is necessary only in case of broadcasting a court hearing). The Law clearly defines the grounds for consideration of case in closed court hearing, when the access to court is restricted for any unauthorized persons and mass media representatives. Thus, the case consideration in closed court hearing is held in cases, when the open consideration may have the disclosure of secret or other information, being protected by law, as a consequence, in case if it is necessary for protection of human personal and family life, as well as in cases, established by law. The case consideration in closed court hearing is held due to motivated court decision.

The procedural legislation of Ukraine, in particular, Article 9 in Economical Procedural Code of Ukraine, warrants the right to receive the information about time and place for consideration of his/her case to everyone; any person, who is not a participant in case, has the access to court hearing due to procedure, established by Law of Ukraine "About Access to Judgments" [3].

The information about the court that considers a case, participants in case, subject of claim and progress of case is open and subject to promulgation at official web portal of judicial power in Ukraine (except the cases that are considered in closed court hearings). Law No 2147-VIII implemented the Uniform Court Information Telecommunication System, which provides with the possibility to submit the procedural applications to the court in electronic form, automatic distribution of cases between the judges of one court that completely excludes the possibility of other's influence on a judge during distribution of cases; exchange of documents in electronic form between a court and participants in case (including sending the summons and copies of judgment), as well as formation and registration of court cases in electronic form that significantly simplifies 
the communication between the court and participants in case and cheapens the legal proceedings; consideration the cases in video conference mode outside court premise in all courts of common jurisdiction.

Now, the Economical Procedural Code of Ukraine (hereinafter referred to as EPC) anticipates the possibility for case consideration due to requirements about collection of monetary debts under contract, concluded in written (including electronic) form, if the sum of claim does not exceed one hundred sizes of minimum wage for able-to-work persons, due to procedure of writ proceedings, without call of persons and performance of court case consideration that significantly simplifies and reduces the procedure of dispute settlement, which are based on effective written (electronic) contracts.

The other novelty in EPC is the consideration of insignificant cases due to procedure of simplified action proceedings, which does not anticipate the performance of preparatory hearing, summon and interrogation of witnesses, performance of judicial debates. Besides, if the case is considered due to procedure of simplified action proceedings, the court is entitled not to perform the court hearing and not to inform the participants in case about its consideration.

The cases, which are not insignificant, are considered by economical courts due to procedure of general action proceedings, which consist of two stages. At the first stage the court performs the preparatory meeting, which purpose is the final definition for subject of dispute; definition of circumstances, which are subject to establishment, and collection of necessary evidences; settlement of recusations; definition of procedure for case consideration and committal of other procedural actions, directed to provide with correct, timely and free settlement of case. The court at the second stage considers the case in essence in open court hearing with notification of all participants in case.

EPC contains a certain chapter, devoted to dispute settlement with participation of judge, which in fact is the mediation procedure, during which a judge may held the joint meetings with participation of all parties and their representatives, as well as closed meetings, which are held at the initiative of judge,- with each party individually.

While holding the common meetings, a judge gives the proposals to the parties as to the ways for peaceful settlement of dispute and carries out the actions, directed to peaceful settlement of dispute by the parties; during closed meetings - a judge pays attention to judicial practice in analogous disputes and offers the possible ways for its settlement.

The procedure for settlement of dispute with participation of judge is finished with establishment of decision about confirmation of amicable agreement (in case of dispute settlement); and in case if a dispute is not settled between the parties, the case is transferred to consideration in essence to another judge.

The grounds and procedure for free legal assistance to the persons, require such assistance, are defined by Law "On Free Legal Assistance", dd. 02.06.2011 No 3460-VI [4].

This Law anticipates rendering the primary legal assistance that includes the provision of persons with legal consultations and composing the procedural applications, as well the secondary legal assistance, which task is the actual representation of person's interests at courts and other authorities.

According to the Law, the right for free legal assistance, being rendered by state establishments, which involve the professional attorneys into this activity, is granted not 
only to citizens of Ukraine and foreigners, persons without citizenship, including refugees or persons, who required the additional protection and are under jurisdiction of Ukraine, providing that their average monthly income does not exceed two sizes of living age.

Verkhovna Rada of Ukraine adopted the new wording of Law "About Executive Proceedings", dd. 02.06.2016 No 1404-VIII, which defines the executive proceeding as a final state in judicial proceeding and enforcement of judgments, in order to improve the progress in fulfillment of judgments [5].

This Law for the first time in history of independent Ukraine along with the institute of state executors implemented the institute of private executors that provides the executors with the right to choose the authority, which will perform the judgment. Besides, the Law significantly extended the powers of executors that assist to improvement of progress in fulfillment of judgments.

\section{Conclusions}

The analysis, being performed, provides with the grounds for conclusion that the modern national legislation of Ukraine on issues of judicial system, status of judges and legal proceedings, adopted within judicial legal reform that actually started in June, 2016, completely considers the international and European standards in the sphere of provision with independence of court and professional judges, observance of judges to the rules of professional ethics, general principals for organization of court activity and communication of court with society, provision with proper quality of justice and efficiency in protection of infringed, challenged or unacknowledged rights of persons.

However, we should consider that the actions, taken within performed reform, are directed to alternative settlement of disputes in Ukraine that requires the adoption of special Law "About Mediation".

\section{References}

1. About Strategy for Sustainable Development "Ukraine - 2020", approved by Decree from President of Ukraine, dd. 12.01.2015 No 5/2015. Legislation of Ukraine [Official website] URL: http://zakon1.rada.gov.ua/laws/show/5/2015.

2. About Judicial System and Status of Judges: Law of Ukraine, dd. 02.06.2016 No 1402-VIII (with changes and amendments). Bulletin by Verkhovna Rada of Ukraine. 2016. No 31. Art. 545.

3. About Access to Judgments: Law of Ukraine, dd. 22.12.2005 № 3262-VI (with changes and amendments). Bulletin by Verkhovna Rada of Ukraine. 2006. № 15. Art. 128.

4. About Court Fee: Law of Ukraine, dd. 08.07.2011 № 3674-VI (with changes and amendments). Bulletin by Verkhovna Rada of Ukraine. 2012. № 14. Art. 87.

5. About Executive Proceedings: Law of Ukraine, dd. 02.06.2016 № 1404-VIII (with changes and amendments). Bulletin by Verkhorna Rada of Ukraine. 2016. № 30. Art. 542.

6. Bangalore Principles for Behavior of Judges, dd. 19, May, 2006, adopted by UN Economical and Social Council, dd. 27.07.2006 № 2006/23. Legislation of Ukraine [Official website] URL: https://zakon.rada.gov.ua/laws/show/995 j67.

7. Code of Judicial Ethics: approved by the XI regular congress of judges of Ukraine on 22, February, 2013. URL: https://zakon.rada.gov.ua/rada/show/n0001415-13\#n4.

8. Conclusion by Consulting Council of European Judges, dd. 19.11.2002 No 3(2002). URL: https://ips.ligazakon.net/document/view/MU02286. 
9. Convention for the Protection of Human Rights and Fundamental Freedoms, ratified by Law, dd. 17.07.1997 № 475/97-BP. (Wording, dd. 02.10.2013). Legislation of Ukraine [Official website] URL: http://zakon1.rada.gov.ua/laws/show/995_004.

10. Conclusion by Consulting Council of European Judges as to Financing and Managing the Courts within Context of Efficiency at Judicial Power, dd. 23.11.2011 No 2 (2001).

URL:http://www.arbitr.gov.ua/files/pages/\%D0\%92\%D0\%B8\%D1\%81\%D0\%BD $\% \mathrm{D} 0 \% \mathrm{BE} \% \mathrm{D} 0 \% \mathrm{~B} 2 \%$ D0\%BE $\%$ D0 $\%$ BA $\% 20 \%$ E2\% $\% 4 \% 96 \% 203$.pdf.

11. Constitution of Ukraine, adopted at the fifth session of Verkhovna Rada of Ukraine on 28, June, 1996 (with changes and amendments). Bulletin by Verkhovna Rada of Ukraine, 1996. No 30. Art. 141.

12. Decision By European Human Rights Court, dd. 12, October, 1978 in case «Zand v. Austria». URL: http://minust.myapp.com.ua/storage/articles/.

ZAND $\% 20 \mathrm{v} . \% 20$ AUSTRIA $\% 20 \% 20[$ Ukrainian $\% 20$ Translation] $\% 20 \mathrm{by} \% 20$ OSCE $\% 20$ Ukraine.

13. European Charter about Law "On Status of Judges", dd. 10, July, 1998. Legislation of Ukraine [Official website] URL: https://zakon.rada.gov.ua/laws/show/994_236.

14. "For Democracy through Law" (by Venetian Commission) as to independence of judicial system.: Report by European Commission, dd. 12-13, March, 2010. URL: https://vkksu.gov.ua/userfiles/.../spil-v-vk-i-dyrektoratu.doc.

15. Fundamental Principles for Independence of Judicial Authorities, approved by resolution 40/32 and 40/146 by UN General Assembly, dd. 29, November and 13, December, 1985 Legislation of Ukraine [Official website] URL: https://zakon.rada.gov.ua/laws/show/995 201.

16. Koverzhev V.O. International Legal Principles for Human Remedies in Business Activity. Consolidation of Principles in the Sphere of Business and Human Rights: Drivers for Ukraine: collection of scientific practical materials of international projects. Scientific Editor V.A. Ustymenko. - Kyiv: NAS of Ukraine, Institute of Economical Legal Researches, 2019. 200 p.

17. Law of Ukraine, dd. 03.10.2017 No 2147-VIII "About Introduction of Changes into Economical Procedural Code of Ukraine, Civil Procedural Code of Ukraine, Code of Administrative Legal Proceedings and other legislative acts". Bulletin by Verkbovna Rada of Ukraine. 2017. No 48. Art. 436.

18. Recommendations to State Members as Actions to Prevent and to Reduce the Excessive Load at Courts, dd. 16.09.1986 № R (86) 12, adopted by Committee of Ministers of the Council of Europe at the 399th meeting of deputy ministers on 16, September, 1986 [Official website] URL: https://www.vkksu.gov.ua/userfiles/doc/perelik.../rek-86.doc.

19. Resolution about Free Legal Assistance in Civil, Economical and Administrative Cases, dd. 18.02.1976 No 76: adopted by Committee of Ministers of the Council of Europe at the 254th meeting of deputy ministers on 18, February, 1976. [Official website] URL:bttps://vkeksu.gov.ua/ userfiles/doc/perelik.../ / rez-76.doc.

20. Recommendations by Committee of Ministers of the Council of Europe as to Actions that Simplify the Access to Justice, dd. 14.05.1981 № $\mathrm{R}$ (81). [Official website] URL: bttps:// zakon.rada.gov.ual laws/show/994_133.

21. Recommendations by Committee of Ministers of the Council of Europe as to Principles for Civil Legal Proceedings, Directed to Improvement in Function of Justice, dd. 28.02.1984 No R (84) 5. [Official website] URL:https://vkksu.gov.ua/userfiles/doc/perelik.../rek-84.doc.

22. Recommendations by Committee of Ministers of the Council of Europe as to Enforcement, dd. 09.09.2003 No Rec (2003) 17. [Official website] URL: https://zakon.rada.gov.ua/laws/show/994 868.

23. UN Leading Principles on Issues of Business Activity within the Aspect of Human Rights. Institute of Economical Legal Researches at NAS of Ukraine [Official Website.] http:/ / www.iepd.kiev.ua. 